\title{
TUDOMÁNY ÉS ÉLETTÉR
}

\author{
Rössler, M. (1990) Wissenschaft und Lebensraum. \\ Geographische Ostforshung im Nationalsozialismus. Hamburger \\ (Beiträge zur Wissenschaftsgeschichte) \\ D. Reimer Verlag, Berlin-Hamburg, 288 o.
}

A könyv egy igen kényes témával foglalkozik. A második világháború óta többször felmerült a kérdés, vajon mennyiben szolgálta ki a náci hatalmat a német földrajztudomány? A szerzô úgy próbálja a választ megadni, hogy egy speciális terület, a Kelet-kutatás történetét vázolja fel. A Kelet a vizsgált idôszzakban az elfoglalt-elfoglalandó lengyel-szovjet területeket, illetve a háború során megszállt csatlós kelet-európai országok területét jelenti.

A munka több kérdést tisztáz. Az egyik legfontosabb, hogy mennyire jelentett a náci hatalomátvétel korszakhatárt a német földrajzban. Ezzel a kérdéssel ugyanis több tanulmány foglalkozott már, gyakorlatilag azt sugallva, hogy a nácizmus ideje alatt mưködõ földrajztudománynak semmi kapcsolata nem volt az elôzményekkel, másrészrổl a háború után sem volt folytatása (a személyekben).

A bổséges hivatkozások, idézetek alapján az derül ki számunkra, hogy a földrajztudomány, a tudósok, oktatók döntố többsége már a Weimari Köztársaság idejében is antidemokratikus, irredenta szóhasználattal élt; indulatoktól, pátosztól gyakran túlfütött, a náci propaganda céljainak megfelelö publikációk születtek, jóllehet gyakran a nácizmus gondolatrendszerétôl függetlenül. A tudományos dol- gozatok érvelésükben következetlenek, bennük a korábbi tudományos eredmények megtagadásával többnyire az érzelmi oldal nyert teret. Sok földrajzos szóhasználatában még jóval a náci korszak elốtt megjelentek azok a szavak, fogalmak, amelyek később az állami ideológia szintjére emelkedtek.

A földrajzosok sem tudták túltenni magukat a versailles-i szerzốdés okozta traumán, de míg Magyarországon Trianon inkább letargiát okozott, Németországban Versailles csak fokozta a radikális, militáns gondolkodás elterjedését.

A szerzõ szerint ezen az antidemokratikus, az élettér (és persze a kutatásra alkalmat adó tér) kiterjesztéséért (legalábbis az elveszett területek visszaszerzéséért) kiálló hajlamon túl más tényezôk is hozzájárultak ahhoz, hogy a földrajzban szinte problémamentesen megtörténhetett a hatalom- és ideológiaváltás, azaz a földrajztudomány (néhány kivételtôl eltekintve) kiszolgálta a nácizmust.

A terror alig játszott szerepet, mert aki idejében nem emigrált, $s$ magában tartotta bíráló megjegyzéseit, nem volt fenyegetve, még egzisztenciájában sem. Példa erre W. Christaller, akire késõbb még visszatér a szerzö, külön fejezetet szentelve munkásságának.

Sokkal fontosabb volt, hogy a hatalom- 
ban támogatót, szponzort láttak a földrajzosok, aminek - a tizenkét év alatt - különbözô megnyilvánulásaival találkozhattak. Elốször is a népi-hazafias nevelésre különösen alkalmasnak ítélt (és tegyük hozzá, kínálkozó) földrajz óraszámát növelték meg jelentôsen az iskolarendszer minden szintjén, ami a földrajztanár képzésben az egyetemeken, fổiskolákon egy addig soha nem látott fellendülést hozott.

A meghódítandó, majd késốbb a már meghódított területek kutatása ugyancsak lényegesnek bizonyult, ami rengeteg új kutatóintézet, szinte megszámlálhatatlan kutatást támogató alapítvány, alap, illetve új egyetemek (Poznan, Prága, Strasbourg) létrehozásában nyilvánult meg.

Ez a fajta Kelet-kutatás eleinte fổleg a meghódított területek jobb közigazgatását, a felhasználható természeti és emberi erõforrások kihasználását, illetve a németek betelepítését, más lakosok kitelepítését szolgálta. (Amint az egy nürnbergi perben kiderült, a földrajz nem számolt tömegmészárlásokkal, a lakosság mozgását mindig „,békés” eszközökkel tervezte elérni. Az egyik intézet vezetôje, nagynevũ földrajzos perében felmentô ítélet született ebben a tekintetben, mivel a földrajz csak annyira volt ,háborús bünös”, mint amennyire az atombombát kifejlesztố tudósok.)

A megszálló szervek, de maga a katonaság is közvetlenül alkalmazott földrajztudósokat, akik fontos adatokkal szolgáltak az ellenséges területekrôl - atlaszokat, értékeléseket, valamint a katonai tereptan számára fontos információkat szállítottak. S direkt szolgálat azonban inkább a háború utolsó három-négy évére volt jellemzô, amikor szinte valamennyi egyetemi földrajzi tanszék, kutatóintézet minden munkatársa többé-kevésbé közvetlenül katonai megrendelésre dolgozott.

A könyv elejétôl a végéig érdekes, lebilincselô olvasmány, ha lehet ilyet egy tudománytörténeti mưrốl mondani. Ennek ellenére csak két dologra térek ki, két olyan tudományterületre, amelyek szinte kizárólag a háborúnak, pontosabban a náci hadvezetés és országvezetés szükségleteinek köszönhetik születésüket. Az egyik ilyen a légifényképek kiértékelése, aminek katonai és polgári jelentôségérôl nem is kell többet mondani. Ez a tevékenység a háború során robbanásszerũ fejlốdésen ment keresztül.

A másik új tudományág a területi tervezés.

A visszaszerzett területek, majd az eredeti országterületet többszörösen meghaladó, elfoglalt területek olyan gondokat jelentettek, amelyekre a német hadvezetés jobban fel volt készülve, mint az igazgatás. Nem tudták, mi legyen a területekkel a gyôzztes háború után. A nagyvonalú tervek ugyanis legtöbbször csak színes térképek voltak Hitler asztalán, nem volt mögöttük semmi. Valójában nem készültek fel a háború utáni idốkre.

Ez a probléma nagy feladat elé állította a német földrajztudományt, mivel nemcsak a területi tervezéssel kellett foglalkozniuk a földrajzot kutat knak, hanem a szakma megteremtése, a képzés tartalmának és kereteinek kijelölése is feladatukká vált. Tegyük rögtön hozzá, a hatalom sok segítséget adott ehhez, míg maga a hagyo- 
mányos földrajz - kivételezett helyzete ellenére (hiszen szinte minden vezetô professzor szoros munkakapcsolatban állt különbözó állami, katonai szervekkel) sosem kapta meg az oktatás terén az erkölcsi támogatás, elismerés mértékének megfelelổ anyagi segítséget.

A tervezésre nézve ez nem állt fenn, a tudósoknak itt nem voltak anyagi nehézségeik.

A területi tervezés pikantériája, hogy az elsố világháborúig német területekre szinte egyáltalán nem terjedt ki, feladata többnyire az , ,új”' hódítások elnémetesítésének (vagy ahogy gyakran teljesen alaptalanul, a történelmi tényekkel ellentétben mondták: visszanémetesítésének) elōkészítése, illetve a lehetốségek felmérése volt. Ezen a területen viszonylag nagy tudományos szabadságot élveztek a kutatók, a szakmai viták - nem egyszer személyes okokból - mindennaposak voltak. Ez azzal is magyarázható, hogy maga a megrendelô, a hatalom sem tudta, mit akar, mert teljesen új tudományággal állt szemben. Így például a tervezốk nyugodtan kimondhatták, hogy a meghódított területek döntố többségét nem lehet elnémetesíteni, mert az olyan mértékú népességcsökkenést okozna az anyaországban, amit az nem lenne képes elviselni.

Egy ilyen kijelentéshez nagy bátorság kellett, mert a német politikának és ideológiának már az elsõ világháború elôtt is sarkalatos pontja volt (a földrajzban is helyet kapott, nem utolsó sorban Ratzelnek köszönhetôen), hogy az ország túlnépesedett, amin nem segithet az ,,impotens", ,,gyáva" intenzifikálás, csak a ter- jeszkedés. Az erre adott válasz tudniillik, hogy nincs elég ember a terjeszkedéshez - majdnem hazaárulást jelentett.

A tervezéssel kapcsolatban tehát néhány szó ide kívánkozik Walter Christaller szerepéról.

Az új területek közigazgatásának létrehozása, egy a megszállás és a leendô elnémetesítés szempontjait kiszolgáló, teljesen új térszerkezet kialakítása volt az igény azokon a területeken, ahol korábban nem éltek németek, így nem lehetett a már/még meglévỗ településekre alapozni.

1933-ban publikált munkájával Christaller szinte semmilyen visszhangot nem váltott ki a szakmában, amihez két dolog is hozzájárult: egyrészt kívülállónak tekintették (harminchat évesen kezdte az egyetemet közgazdász hallgatóként), másrészt kifejezett baloldali beállítottsága miatt (rendốrségi akták készültek a diákmozgalomban betöltött szerepérốl) nem volt népszerũ a konzervatív professzori kar körében.

1937-ben viszont éppen valami olyanra volt szükség, amit ố csinált. Matematikailag jól megfogható, világos, tisztán hierarchizált településszerkezet, a központi helyek hálózata és a köztes helyeket kitöltô kisebb települések. Ennek köszönhette, hogy az SS egyik kutatóintézetében dolgozhatott a háború befejeztéig. A háború menete nem adott lehetôséget arra, hogy tervei megvalósuljanak, de a történelem fintora, hogy a németek által megszállt lengyel területekre elkészített térszerkezeti-településfejlesztési terveit a lengyel hatóságok a háború után az újonnan szerzett német és a háborúban el- 
néptelenedett lengyel területek benépesitésénél felhasználták.

A könyv utolsó fejezetében, rövid összefoglalásként Rössler ítéletet mond a hatalom kiszolgálásában részes tudósokról:

A háború után - kevés kivétellel minden korábbi professzor, egyetemi oktató többnyire a hábonú elốtti munkahelyén, tanszékén folytathatta munkáját. Ennek egyik oka az volt, hogy a megszálló hatalmak is érdeklôdtek a német földrajzosok katonailag hasznosítható eredményei iránt, másik oka, hogy a nácitlanítás a nyugati megszállási zónákban messze nem öltött olyan méreteket, mint Keleten. Harmadik okként említhetô, hogy nemigen tudtak mit rábizonyítani a néhány prominens, bíróság elé állított földrajzosra. A párttagság bocsánatos bünnek számított, az pedig tény volt, hogy a földrajztudomány egyetlen embert sem ölt meg. Többen azzal védekeztek, hogy tiszta tudományos eredményeket alkottak, amit a hatalom ugyan felhasznált, de ez már nem az ố bûnük.

Így történhetett, hogy a konzervatív, antidemokratikus hagyományok az annak megfelelổ gondolkodásmóddal együtt átmentổdtek, sổt átadódtak. A legfontosabb német földrajzi mühelyek, egyetemi tanszékek a háboní után is a nácik idején kinevezett professzorok vezetése alatt mûködtek tovább, és nevelték a tanárok, kutatók nemzedékeit.

A történelem igazságtalansága, hogy az a néhány ember, aki emigrációba kényszerült az üldöztetések elôl, nem jutott pozícióhoz a háború után sem, mert helyüket
- egyfajta cinkos összetartás alapján azok foglalták el, akik korábban feljelentették, támadták ő́ket.

Christaller is hasonló sorsra jutott. A náci hatalomátvétel után Franciaországba menekült, majd visszatért. Annak ellenére, hogy tulajdonképpen SS-alkalmazásban állt (bár hivatalosan, mint annyi más kollégáját, egy vagy több kutatási alap fizette), szinte mindig figyelte ốt a rendốrség, mert ismert volt baloldali múltja. A hábonú után viszont SS-múltja miatt indítottak vizsgálatot ellene. Munkásságát amerikai földrajzkutatók értékelték, de abban csak tiszta szakmai szempontok érvényesülését találták, szakvéleményük alapján elejtették az ellene emelt vádakat.

A háború után a Német Kommunista Párt, majd késôbb az SPD tagja lett.

A szerzô súlyos vádakat említ, de személy szerint tudja igazolni azokat. Nemcsak az akkor született publikációk, kéziratok elemzését végezte el Rössler, hanem a levelezések, jegyzőkönyvek, levéltári anyagok feldolgozását is, tehát nem támadható.

Az érintettek szinte kivétel nélkül meghaltak már, ezért a megállapítások nem a jelenlegi földrajztudósok ellen irányul. Annyiban mégis, hogy a most élố, alkotó generációk eddig többé-kevésbé igyekeztek tisztára mosni tanáraikat - tetteiket elbagatellizálni, a tudomány, a háború, az erkölcs szempontjából jelentéktelennek beállítva azt, amit a náci korszak tizenkét évében, illetve elốtte és utána alkottak.

A könyv ebben a tekintetben hiánypótló, leleplezố és tisztázó szerepet tölt be. A szerzônek is az a véleménye, hogy nem 
maga a tett, az együttmưködés volt a bũn, hanem az, ahogyan ezt késóbb helyesnek, természetesnek állították be az érintettek. Nem kértek elnézést félreállított kollégáik- tól, az emberiségtổ, mivel úgy gondolták, nem követtek el semmit.

Kocsis Zsolt

\title{
A FÖLDRAJZ - ÚTON A POSZTMODERNBE?
}

\author{
Krüger, $R$. (1988) Die Geographie auf der Reise in die Postmoderne? \\ Wahrnehmungsgeographischen Studien zur Regionalentwicklung, 5. \\ Bibliotheks- und Informationssystem der Universität Oldenburg, 1060.
}

A szerző gyakorló területfejlesztô, könyve azonban a posztmodern geográfiáról szóló, túlnyomórészt filozófiai fejtegetéseket tartalmaz.

Az elôszzóban rendhagyó módon definiálja a posztmodernt, a meghatározás azonban a tanulmányban újabb és újabb jelentésekkel bổvül. Mégsem ebbốl a dolgozatból tudhatjuk meg, mi is a posztmodern. Nem is ez a fontos, hanem az, hogy a posztmodern (és ezen most a korszak, az ember, a társadalom egyaránt értendô) miként viszonyul az endogén regionális fejlesztéshez.

A kiindulóhelyzet: az informatika, az automatizálás, a csúcstechnológia és a tốkekoncentráció odavezettek, hogy a régi, hagyományos ipari területek és a tradicionális, kevésbé fejlett területek közötti ellentétek részben áthelyezôdtek, illetve a hagyományos ipari zónák és az új, csúcstechnológiát alkalmazó szilícium-völgyek között/közé kiéleződtek. Az eddig elmaradott térségek számára ugyanakkor éppen ez jelentheti a jövốt, az esélyt, mert a ter- melés rugalmasabbá válásával a telephelyválasztás könnyebb, azaz megteremtôdhet a telephelyek (térségek) közötti esélyegyenlốség. Ez nemcsak a tốkés ,,kizsákmányolás", a kapitalista verseny élét tompítja, hanem a munka társasági-, szövetkezeti formáinak is lehetốséget biztosít.

A gazdasági, és így a politikai hatalom is szétterül a térben, a termelốegységek egyre kevésbé veszik igénybe kömyezetüket, ezért maga a termelés kevésbé monokultúrás jelleget ölthet, hiszen adott területen többféle tevékenység megtelepülhet. $\mathrm{Ez}$, valamint a kisebb szervezetekbốl adódó döntéshozatali decentralizáció, illetve dekoncentráció kezelhetốbbé teszi a konfliktusokat.

A tradicionális urbanizáció problémái, a városon belüli és a városok közötti fejlốdés-hanyatlás polarizáció ellenére is perspektíva nyílik az urbanizáció, egy új urbanizáció számára. Ez persze nem jelenti azt, hogy az elmaradott területekre csúcstechnológia telepítése lenne az endogén regionális fejlesztés módszere, vagy 